Jurnal Ilmu Budaya, Vol. 18, No. 1 Agustus Tahun 2021

\title{
THE ANALYSIS OF ILLOCUTIONARY ACTS IN COMIC "THE ADVENTURES OF TINTIN VOLUME 8"
}

\author{
Sryetti Septiana Sibuea \\ Universitas Lancang Kuning, Pekanbaru \\ Email: sry.7bu34@gmail.com
}

\begin{abstract}
This research discusses the types, functions and dominant types contained in the conversation of the main character in the comic of "The Adventures of Tintin Volume 8 ". Comic is one of the picture books which are popular with youth and children. This comic tells the characters of Tintin, who as the main character, plays as detective. A picture that represent the character's actions reinforces each utterances presented by characters. The focus of the study in this discussion is to answer the research statement, namely the types of Illocutionary Acts in the Comic " The Adventures of Tintin Vol 8 " and the functions as well as the dominant types found in the conversation. In this research, the writer found out the types of Illocutionary acts from the 3 stories are Representative, Directive, Expressive and Commissive. From the 3 stories there are slightly different functions depended on the situation of the each stories. The dominat types are Representative. Its shows that Tintin representing the statment from his acts to make the listener belief to his word.
\end{abstract}

Keywords: Pragmatic, Illocutionary Acts, Comic

\section{Introduction}

When speakers and listeners communicate, it is not simply about conveying information to others but how listeners should interpret the meaning of utterances. In order to express the meaning of utterances, the speakers and listeners must be able to consider the condition when, where and to whom they speak. The study of meaning which is based on context of situation, who is speaking, and to whom is described is called Pragmatics. Pragmatics has a special field of study to examine the meaning of language in every utterances based on context, namely speech acts. Speech acts are used to describe such language actions through of utterances (Yule: 1996). It means, speech acts is 
Jurnal Ilmu Budaya, Vol. 18, No. 1 Agustus Tahun 2021

concerned with the context of language use.

Speech acts are divided into three types of utterances: Locutionary, Illocutionary, Perlocutionary. Languge that uses in utterances are divided into two based on the media used : spoken and written language. Comics is one of example of spoken language as one of the popular books, comics are much in demand by youth and children. It is pictorial writing media which are used to express ideas accompained by text. The picture here have fuctions as an illustration to strengthen the action in the comic.

One of example the popular adventure comic is "The Adventures of Tintin volume 8 “. This comic was written by a Belgian cartoonist, Herge in 1929. In this story's conversation there are many phenomena of language use, one of which is utterances which are influenced by the situation and character. So the meaning must be addressed based on the context of the speaker.
Based on the statment above the writer tried to formulate the questions as follow: 1. What are the type of Illocutionary Acts in the comic "The Adventures Of Tintin Vol 8 "? 2. What functions are there in the Illocutionary Acts in the comic "The Adventures Of Tintin Vol 8 "? 3. What are the types of Illocutionary Acts which are mostly found in the comic". The Adventures Of Tintin Vol 8 "? The objectives of the study intend of figure out the following description are: 1. To identify the types of Illocutionary Acts in the comic of " The Adventures Of Tintin Vol 8“، 2. To describe and analyze the function of Illocutionary Acts in the comic " The Adventures Of Tintin Vol 8“, 3. To describe the dominat types of Illocutionary Acts in the comic "The Adventures of Tintin Vol 8“.

\section{Theoretical Framework}

\section{A. Pragmatics}

According to Leech (1993: 8) pragmatics is the study of meaning in relation to speech 
Jurnal Ilmu Budaya, Vol. 18, No. 1 Agustus Tahun 2021

situations which includes

addressed, context, purpose, illocutionary acts, speech, time and place. The meaning is not only based on the word, but it depends on the context of the situation. It means, pragmatics study is more focused on meaning and context. Moreover, Yule (1996: 3) explains that pragmatics is the study of how listeners can make inferences about what is said in order to arrive at an interpretations of speakers' intended meaning. Pragmatics focuses more on how speakers and listeners interact on context.

\section{B. Illocutionary Acts}

Illocutionary act is an act is an act performed in uttering a sentence; it is the making of a statement, an offer, a promise, etc. According to Searle (1969: 25), the illocutionary act was an act performed in saying something. On other words, illocutionary act could be defined as used a sentence to perform a function. Illocutionary act was the real actions which were performed by utterance. There are five basic kinds of speech act of utterance that one can perform in speaking which are promoted by Searle in Levinson (1983:240), they are representative, directives, commissives, expressive, and declarative.

\section{Theory of Comic}

Comics become the predominate place in culture which this visual language is used, often paired along with writing a learned importation of the verbal modality into the visual - graphic. Comics is written in both a visual language and a written language - reflecting the multimodality of human expression found in co - speech gestures (Clark, 1996; McNeil, 1992, 2000). The words functionally dominate the image, it then becomes merely illustration to a text. According to Nurgiyantoro (2005: 409), the images in the comic is an arrest of scene event by event, as a representation of the 
story conveyed with display figures and background. It means, the images in comic have an important role to describe determine the actions of each character. All of comics text are arranged in relation to images (visual) and words (verbal).

\section{Methodology of Research}

\section{A. Kind of Research}

This research is based on the Library Research. Library research is a data collection method that uses theoretical studies from previous research to obtain information about research of the topic. A library research generally includes primary and secondary sources.

\section{B. Source of Data}

Data is a collection of information obtained the observations in the form of numbers, symbols and the others. The writer uses the primary sources of data from the comic with the title is "The Adventures Of Tintin vol
8“, published in 2015. There are three stories in the comic as the data that are used as material for the writer's analysis.

\section{Data Collecting Technique}

The accurate data for the research, the writer has taken from the dialogue of the characters in the comic of " The Adventure of Tintin Vol 8 ". To get the data, the writer will do the technique close reading and observation. In the comic of The Adventures of Tintin Vol 8 consists of three stories which have many characters. To make the research more easier, the writer will take the data in the form of the utterances by one of the the main characters, Tintin.

\section{Data Analyzing Technique}

Data analyzing is the collecting and organizing of the data so that a researcher can come to a conclusion. In this term, the writer uses Descriptive Qualitative to collect the data information on descriptive in the 
form of written or oral words of people and behavior that can be observed thoroughly about form, function and meaning of the expression (Robert \& Taylor, 1975).

\section{Findings}

The writer would like show and explain the results of analysis and observation completely in the comics of" The Adventures of Tintin Volume 8 ". In the comic the writer analyzes the Illocutionary Acts contained in the utterance of the main character, Tintin. The writer collected the data through an analysis of the types and functions of the Illocutionary Acts; Representative, Directive, Expressive, and Commissive. Then proceed to analyze the dominant types of Illocutionary acts in the comic. This comic is divided into three different stories with adventure themes.

The writer will present analytical data obtained from the comic. The comic consists of three stories with different themes so that the writer uses three tables to make it easier to analyze each stories.

1. Flight 714 To Sydney

\begin{tabular}{|l|c|c|}
\hline No & Type & Total \\
\hline 1. & Representative & 77 \\
\hline 2. & Directive & 77 \\
\hline 3. & Commissive & 4 \\
\hline 4. & Expressive & 8 \\
\hline
\end{tabular}

2. Tintin and The Picaros

\begin{tabular}{|l|c|c|}
\hline No & Type & Total \\
\hline 1. & Representative & 77 \\
\hline 2. & Directive & 51 \\
\hline 3. & Commissive & 13 \\
\hline 4. & Expressive & 16 \\
\hline
\end{tabular}

3. Tintin and Alph - Art

\begin{tabular}{|l|c|c|}
\hline No & Type & Total \\
\hline 1. & Representative & 75 \\
\hline 2. & Directive & 42 \\
\hline 3. & Commissive & 1 \\
\hline 4. & Expressive & 4 \\
\hline
\end{tabular}

The analysis of utterances of Representative can be seen bellow: 
Captain Haddock: "I didn't see the plane : must have been camouflaged.“

Tintin : "I expect so. "

Tintin : "We must be getting near : look at Snowy. He's on to something".

Tintin : "Crumbs! Another bunker, with two guards outside. That'll be where they're holding Carreidas “( ( P. 31 ).

The utterances above can be interpreted as Representative Illocutionary Acts. The dialogue takes place between Captain Haddock, Tintin, and Snowy, his dog. At that time they were looking for $\mathrm{Mr}$ Carreidas who is a Rastapopolous prisoner, with Snowy's agility, they were able to find the Rastapopolous hideout bunker. The utterances show that Tintin describing the conditions of the Rastopopolous' bunker place which they found. When Tintin and Captain haddock observed the bunker of Rastopopolous, Tintin inform to his friend that "... Another bunker, with two guards outside. That'll be where they're holding Carreidas". This utterances of Tintin can be grouped into Representative which function as an Informing.

The analysis of utterances of Directive can be seen bellow :

Tintin: " But anyway, why all the palaver? ... And who wants to kill us ?" ( P.90 )

Pablo: "The official version : the Picaros tried to kidnap you ! “ Literally, the utterances above are interpreted as Directive Illocutionary Acts that function as Asking. The dialogue between Tintin, Pablo and Captain Haddock at the Apartment emphasizes Tintin's curiosity as to who will kill them. Tintin Asks "But anyway, why all the palaver? ... And who wants to kill us ?". It means that tintin wants to know who exactly will kill them. These utterances are function of Directive as Asking.

The analysis of utterances of Expressive can be seen bellow :

Tintin: "Oh ! Come and look ... quietly ... “ 
Jurnal Ilmu Budaya, Vol. 18, No. 1 Agustus Tahun 2021

\section{Tintin: “Rastapopolous wasn't exaggerating: the safety net's gone the runway's almost disappeared. I must admit, the operation was organized down to the last detail. "(Р.31)}

These utterances show Tintin's reaction to admit that Rastapopoulos's crime plan was arranged in a neat and detailed. Tintin and Captain Haddock watched the activities of Rastapopoulos's men from behind a big rock which eliminated the runway footprint they had made. Tintin amit that "Rastapopolous wasn't exaggerating: the safety net's gone the runway's almost disappeared. I must admit, the operation was organized down to the last detail. ". In this case, the utterances above can be interpreted as Expressive Illocutionary Acts which functions as Complimenting.

The analysis of utterances of Commisive can be seen bellow :

Tintin : "We've wasted enough time. Let's go, I'll see if the coast's clear“( ( P.35).
Captain: "Yes, yes do that. I'm coming".

This utterances can clearly be interpreted as Commissive Illocutionary Acts which in this utterances express the act of Tintin which leads them out of the bunker so that they are safe from other bandits. Tintin offer to Captain Haddock that "We've wasted enough time. Let's go, I'll see if the coast's clear "at that moment Captain Haddock was removing the plaster that was on his finger. From this, it can be seen that these utterances are a function of the Commisive as an Offering.

Based on the analysis table above, it can be seen that in the first, second, and third stories have a dominant equation of the Illocutionary Acts type, namely Representative, although each story has a different theme. Representative potentially representing the statement of committing the truth of the fact which intends to make the listener believe to the speaker. In the utterancances produced by Tintin many use 
Representative because each story uses the theme of investigation which presents many statements made by Tintin to support his investigation of solving the problem.

\section{Conclusion}

Based on the discussion of the analysis previously stated, it can be concluded that in the comic of "The Adventures Of Tintin Volume 8 “ which consists of three different stories with the same theme, there are four types of Illocutionary Acts that found in the utterances by Tintin. The four types are Representative, Directive, Commissive, and Expressive. In each types there are several different functions, Representative are included informing, calling, asserting, predicting, believing, affirming, concluding, stating, encouraging, and reteling. Directive consists of asking, ordering, commanding, suggestion, forbidding, begging, and warning. Commissive consists of refusing, offering, promising. The last is Expressive are divided into apologizing, appreciating, thanking, greeting and disappointing.

In the three stories mentioned in the data of Tintin's utterances, it can be seen that the most dominant types is Representative which functions often found are stating, informing, and affirming. This type describes how the speaker (Tintin) tries to represent the truth to make his friends (listener) listen and believe in his word. Each of utterances in the stories is base on the context to find out the meaning of utterances.

\section{BIBLIOGRAPHY}

Bodgan, Robert \& Steven Taylor. 1975. to Qualitative Research Methods: A phenomenological Approach to the Social Sciences. New York: John Wiley and Sons.

Dyrandi. Blogspot. Com, accesed on April 3, 2015.

Clark, M.H. 1996. Using Language. Cambrige MA: MIT Press.

Gumelar, M.S. 2011. Comic Making. Jakarta: PT Indeks.

Halliday, M.A.K. 1990. Spoken and Written Language. Oxford University Press. 
Jurnal Ilmu Budaya, Vol. 18, No. 1 Agustus Tahun 2021

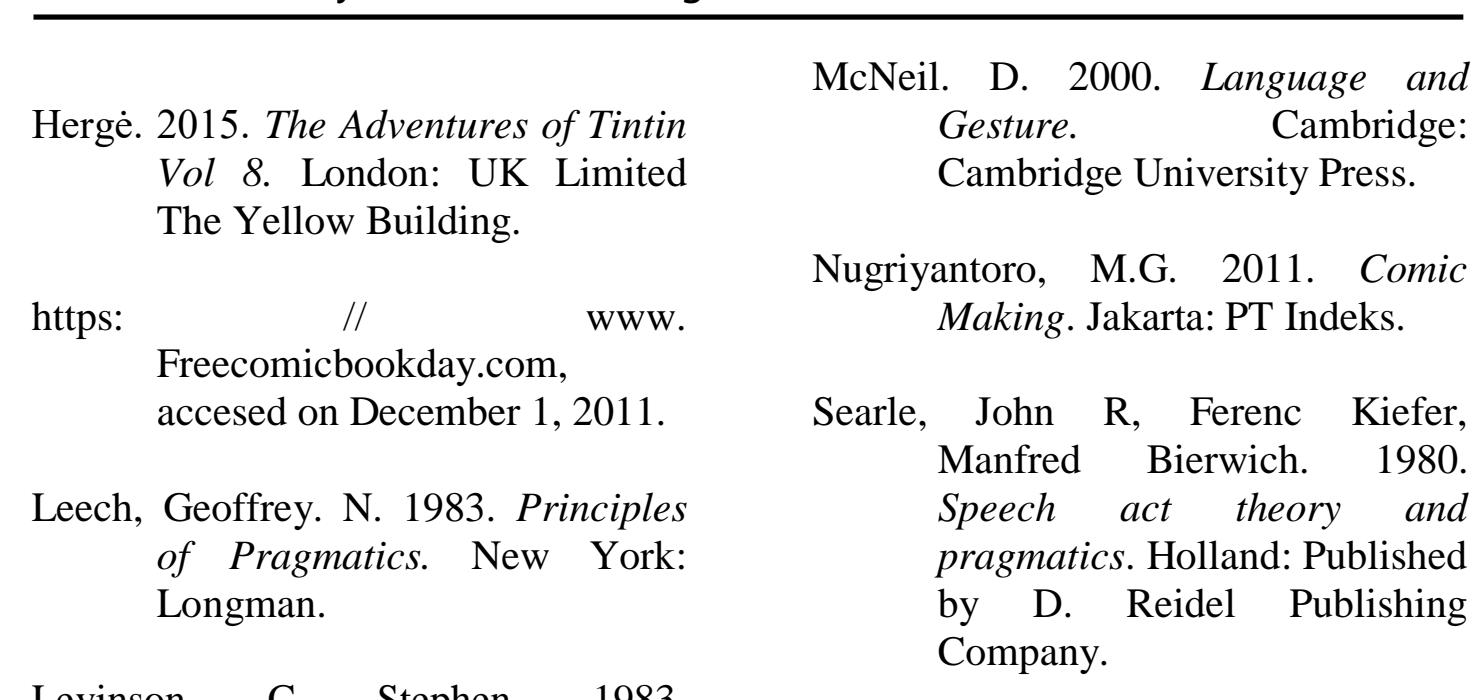

Levinson, C. Stephen. 1983.

Pragmatics. New York: CUP. 